\title{
Blasts 20 Percent or More of Bone Marrow Nucleated Cells
}

National Cancer Institute

\section{Source}

National Cancer Institute. Blasts 20 Percent or More of Bone Marrow Nucleated Cells. NCI Thesaurus. Code C36214.

A semi-quantitative microscopic finding indicating that 20 percent or more of the nucleated cells in a bone marrow sample are immature mononuclear cells. 